\title{
Reduction of liver mass due to malnutrition in rats. Correlation with emaciation of animals and size of organs not inserted in the portal system
}

Department of Histology and Embriology of the Instituto de Ciências Biomédicas of the Universidade de São Paulo and II Surgical Division, Faculdade de Medicina de Sorocaba of the Pontifícia Universidade Católica - Sorocaba, Brazil

We studied the effects of protein-energy malnutrition on the liver morphology of rats as compared to animal emaciation and to reduction in size of the organs not irrigated by splanchnic blood such as kidneys and spleen. The animals were divided into two groups, one of them fed ad libitum rate $(\mathrm{N}=10)$ and the other $(\mathrm{N}=14)$ receiving water but no food for 7 days, and the changes in animal weight, liver, kidney and spleen mass were determined. DNA and the protein/DNA ratio, as well as hepatocyte size, were determined in liver tissue. The liver decreased in mass $(27.14 \%)$ at a significantly higher proportion $(p<0.05)$ when compared to body emaciation $(19.22 \%)$. Similar to the reduction in body weight, the masses of kidneys and spleen were reduced by $18.68 \%$ and $24.28 \%$, respectively. The reduction in liver mass occurred due to hypoplasia and atrophy, i.e., a decrease in hepatocyte number and size, respectively. We conclude that there is a preferential consumption of liver protein in protein-energy malnutrition which is suggested to result from the additive action of the effects of overall consumption of organic reserves due to malnutrition proper and to the reduction of the hepatotrophic stimulus.

UNITERMS: Atrophy. Liver. Glucagon. Insulin. Liver regeneration. Malnutrition. Starvation.

$\mathrm{P}$ rotein-energy malnutrition is accompanied by metabolic changes whereby the organism attempts to guarantee an energy supply to very important organs such as the heart and brain at the expense of fat and structural protein consumption(10). The result is emaciation or loss of body weight including the protein mass of some internal organs, the liver in particular $(1,2)$. In addition, there are concomitant changes in hormonal homeostasis that involve the availability of some of the so called hepatotrophic factors $(4,9,11,12,14,19,48,49)$. The aim of the present investigation was to study morphometric and biochemical liver changes in malnourished rats and to correlate them with the reduction in mass of organs not irrigated by splanchnic blood, such as kidney and spleen, and not directly depending on portal hepatotrophic factors.

\section{MATERIAL AND METHODS}

Female Wistar rats weighing approximately $200 \mathrm{~g}$ were identified individually and divided into two groups submitted to the following procedures:

\author{
Address for correspondence: \\ Osório Miguel Parra \\ Rua Aibi, 70 \\ São Paulo - SP - Brasil - CEP 05054-010
}


Group A (control) - Ten animals were placed in a single cage containing water and food ad libitum and left there for 6 days.

After a 24 hour fast, the animals were sacrificed by ether inhalation on the 7 th day and laparotomized. The liver, spleen and both kidneys were removed, blotted dry on filter paper and weighed. Small fragments were removed from the liver and fixed in 10\% formalin for morphometry, and a larger fragment was immediately weighed, identified and frozen for later biochemical determinations.

Group B - Fourteen animals were placed in a single cage and left there for 7 days with water ad libitum but no food. At the end of this period the animals were sacrificed by ether inhalation, weighed and submitted to the same procedures as described for the control group.

Indices relating animal weight to the weight of the organs studied (liver, spleen and kidneys) were extracted from group A (control) and used to estimate the initial weight of these organs in the living animals of group B. The percent decrease in mass of each of the organs studied was then calculated at sacrifice using the formula: estimated initial weight - observed final weight $\times 100$ estimated initial weight

Biochemical DNA measurement was performed after extraction with trichloroacetic acid using the diphenylamine reaction $(8,34)$ and liver tissue protein was measured by the method of LOWRY (29). The results of both measurements are reported as concentrations $(\mathrm{mg} / \mathrm{g}$ liver) and as protein/DNA ratio.

The total initial DNA and protein liver masses of group B animals were calculated from liver weight estimated at the beginning of the experiment multiplied by DNA and protein concentrations, respectively, in the liver parenchyma of group A (control) animals. The total final masses were obtained by multiplying the final weight of the livers of group B animals by the respective DNA and protein concentrations. The data were then used to calculate the difference between values at the initial time and at the time after malnutrition (percent variation).

The liver fragments fixed in formalin were routinely processed by paraffin embedding, cutting into $6 \mu \mathrm{m}$ sections and staining with hematoxylin-eosin (HE). Considering the number of nuclei per prefixed area as an indirect measurement of cell size, i.e., the larger the number of nuclei the smaller the cell size (24), the nuclei present in 4 fields obtained at random from the liver of 5 animals per group were counted. Counts were done on fields covered by a $0.0534 \mathrm{~mm}^{2}$ square obtained with a $10 \mathrm{X}$ grid eyepiece and a $40 \mathrm{X}$ objective attached to a binocular Zeiss microscope. Fields containing portal spaces and centrolobular veins were not considered.
Statistical analysis: The results are reported as means and standard error of the mean. Groups were compared by the Student t-test for two independent samples or for paired samples when comparisons were made within group B. Multiple comparisons were made by analysis of variance and the discrimination between groups was performed by the Newman-Keuls test. The level of significance was set at $\mathrm{p}<0.05$.

\section{RESULTS}

Mean body weight and weights of the organs studied for group A are presented in Table 1 .

Table 1

Weights $(\mathrm{g})$ observed in group $A$ animals

\begin{tabular}{cccc}
\hline Body mass & Liver & Spleen & Kidneys \\
\hline $183.9 \pm 1.4$ & $6.25 \pm 0.24$ & $0.48 \pm 0.021 .26 \pm 0.04$ \\
\hline
\end{tabular}

The organ weight/body weight ratios listed in Table 2 show that, under the effect of prolonged starvation, the liver decreased in weight proportionally more than the other organs, with a significant change in its relation to body weight.

Table 2

Organ weight/body weight (b.w.) ratio of control animals (Group A) and of experimental animals (Group B at sacrifice)

\begin{tabular}{|c|c|c|c|}
\hline Group & Liver/b.w. & Spleen/b.w. & Kidneys/b.w. \\
\hline A & $0.0339 \pm 0.0012$ & $0.0026 \pm 0.0000$ & $0.0068 \pm 0.0001$ \\
\hline B & $0.0304 \pm 0.0005$ & $0.0026 \pm 0.0000$ & $0.0070 \pm 0.0001$ \\
\hline & $p<0.01$ & ns & ns \\
\hline
\end{tabular}

$\mathrm{ns}=$ not significant

Table 3 reports the percent decrease in body and organ weight caused by malnutrition in group B animals. The decrease in liver weight, when presented in this manner, was also proportional and significantly greater than that of other organs in relation to emaciation. 
Table 3

Emaciation and decrease in organ weight in group B animals (\%)

\begin{tabular}{lll}
\hline Emaciation & Liver & Spleen \\
\hline
\end{tabular}

$19.22 \pm 0.45^{*} 27.41 \pm 1.24^{*} \quad 24.28 \pm 3.54 \quad 18.68 \pm 1.96$

${ }^{*} \mathrm{p}<0.05$ by analysis of variance and the Newman-Keuls test.

Table 4 compares the DNA and protein concentrations and the protein/DNA ratio in the liver parenchyma of the animals of both groups. The table also compares the number of nuclei/area, an indirect measurement of hepatocyte cell size.

\section{Table 4}

Liver DNA and protein ( $\mathrm{mg} / \mathrm{g}$ liver) concentrations and protein/DNA ratio. Number of hepatocyte nuclei per area

\begin{tabular}{cccc}
\hline $\begin{array}{c}\text { Group DNA } \\
\text { concentration concentration }\end{array}$ & $\begin{array}{c}\text { Protein/DNA } \\
\text { ratio }\end{array}$ & $\begin{array}{l}\text { Number of } \\
\text { nuclei/area }\end{array}$ \\
\hline
\end{tabular}

A $1.949 \pm 0.068136 .64 \pm 5.4470 .50 \pm 2.83 \quad 179.8 \pm 6.9$

B $2.106 \pm 0.069123 .04 \pm 4.5058 .89 \pm 2.15241 .8 \pm 5.2$

\begin{tabular}{cccc} 
ns & ns & $p<0.01$ & $p<0.001$ \\
\hline
\end{tabular}

$\mathrm{ns}=$ not significant.

Table 5 reports the percent variation in total DNA mass and protein mass per liver in the animals of group B between the beginning of the experiment (estimated values) and the end of the 7-day period of starvation.

Table 5

Total DNA and protein contents ( $\mathrm{mg} / \mathrm{liver}$ ) before and after malnutrition in group $B$ animals

\begin{tabular}{ccc}
\hline $\begin{array}{c}\text { Estimated } \\
\text { initial mass }\end{array}$ & Final mass & $\begin{array}{c}\text { Percent } \\
\text { variation }\end{array}$ \\
\hline
\end{tabular}

DNA $\quad 12.392 \pm 0.333^{*} \quad 9.649 \pm 0.284^{*} \quad-21.81 \pm 2.30+$ Protein $868.33 \pm 23.35^{\star \star} 567.13 \pm 16.68^{* *}-34.64 \pm 1.12+$

${ }^{*} p<0.001 ;{ }^{* *} p<0.001 ;+p<0.001$

\section{DISCUSSION}

Several substances such as nutritional elements and hormones, primarily represented by insulin and glucagon, have been reported to be factors contributing to the hepatotrophic effect of portal blood responsible for the morphofunctional status of hepatocytes $(3,7,13,15,19,33,42,43,52)$. Carbohydrate, proteins and amino acids absorbed in the intestine, in addition to contributing with energy and structural elements for cell maintenance and renewal (15), also act indirectly by stimulating the production of factors such as insulin itself $(17,20,21,22)$. Thus, it is to be expected that prolonged nutritional deprivation and the consequent alterations in metabolism and hormonal homeostasis will affect liver trophism and the maintenance of liver structure by decreasing insulin availability $(4,9,11,48)$, by changing the insulin/glucagon molar ratio $(12,14,48,49)$, and by reducing portal speed and flow (31). In models of regenerative stimulation by partial hepatectomy, it has been demonstrated that malnutrition, and protein malnutrition in particular, acts as an inhibitory factor of hepatic regeneration $(6,41,46,47)$.

Food deprivation for a period of 7 days caused a $19.22 \%$ reduction in body weight in the animals used in the present experiment (Table 3 ), similar to the $23.1 \%$ value obtained by ADDIS et al. (1) and the $18 \%$ value reported by SKULLMAN et al. (41). It is interesting to note that kidney and spleen masses were decreased in proportions similar to body weight loss, but that the liver, an organ inserted in the portal circuit, presented a proportionally greater decrease, so that its relation to body weight was significantly modified $(\mathrm{p}<0.001)$ (Tables 2 and 3 ), a fact also observed by SKULLMAN et al. (41).

Work by ADDIS et al. $(1,2)$ has shown that the liver, among all organs, loses greater amounts of protein at a faster rate, with a $20 \%$ loss within as little as 2 days. We believe that the "preferential" consumption of this protein reserve is also due to another additional effect. It is known that shunt of the hepatopetal flow is accompanied by liver atrophy $(37,38)$, a fact attributed to the reduction of hepatotrophic factors such as insulin $(33,43)$. Thus, the prolonged lack of food ingestion reducing the generation of hepatotrophic factors, creates a condition of relative insulin insufficiency (19), and possibly other factors, similar in its effects to that provoked by surgical shunt of hepatopetal flow. This fact is probably responsible for the greater reduction in liver mass in relation to body emaciation and mass of kidney and spleen, organs that do not depend directly on the splanchnic blood, in an additive 
action with respect to mass reduction that would be expected as a function of simple protein consumption caused by malnutrition.

The role of glucagon is less clear since reports that have related it to the trophic/regenerative stimulus are sometimes conflicting, now showing that glucagon is important for this process in rats and mice $(3,7,18,27)$, now showing that it plays no part in dogs $(3,44,45)$. However, several studies have shown that glucagon plays at least an adjuvant role in the generation of the stimulus by mechanisms such as synergism with insulin $(7,51)$, maintaining glucose supply in the presence of high insulin levels (12), stimulating amino acid transport (16) or increasing portal flow $(28,32)$, actions that are certainly altered by prolonged fasting.

The reduction in liver mass seems to have occurred in two ways, i.e., by a decrease in cell number (hypoplasia) reflected by the decrease in liver size with small variations in tissue DNA and protein concentrations (Table 4) or by the significant reduction in total DNA and proteins (Table 5 ), and by the reduction in size of the remaining hepatocytes (atropy), as suggested by the increased number of nuclei per area $(\mathrm{p}<0.001$, Table 4$)$, an indirect measurement of cell size, and by the significant decrease $(\mathrm{p}<0.001)$ of the protein/DNA ratio. A decrease in this ratio and a similar conclusion were reported by YOUNG et al. (53) in a study of low-calorie diets. The decrease in hepatocyte size by reduced insulin availability has been previously shown by STARZL et al. $(42,43)$ in experiments with selective portal infusions.

It is also interesting to note that the reduction in hepatic tissue protein per liver $(-34.64 \%$, Table 5$)$ was significantly greater $(\mathrm{p}<0.001)$ than the reduction in DNA $(-21.81 \%)$, a value that roughly represents the number of hepatocytes. Since this value is proportionally similar to the decrease in body weight (19.22\%) and kidney weight
(18.68\%), it may be assumed that hypoplasia (decreased number of cells) was mainly due to prolonged malnutrition, accompanying the process of general consumption, whereas atrophy (reduction in cell size) was due to a reduction of the hepatotrophic stimulus, i.e., to the reduced availability of factors mainly represented by insulin. Although speculative, this hypothesis agrees with data reported by SIEGEL et al. $(39,40)$ who were able to separate and individualize the hyperplastic and hypertrophic stimuli, the latter being more related to the availability of portal factors. In heterotopic transplants of autologous liver lobes associated with Eck fistulae, these investigators showed an attenuation of the cell atrophy process compared to controls without Eck fistulae, possibly because portal factors such as insulin, which is largely extracted during its first passage through the hepatic bed $(5,30,31)$, by not being consumed as a function of the portocaval shunt, may reach the autografts via the arteries in a larger proportion.

The process described here, i.e., hepatic hypoplasia and atrophy, due to malnutrition with the probable participation of a decreased supply of hepatotrophic factors, is in contrast to data observed in previous studies in which the intraperitoneal (portal) infusion of additional exogenous hepatotrophic factors caused an increase of as much as $86 \%$ in the hepatic mass of intact livers, with a mean value of $67.54 \%(35,36)$ reproducing, in a way, the increase in liver mass observed when a liver is transplanted into a recipient of larger size than the donor $(23,25,26,50)$. This shows that, from a morphological viewpoint, the liver and its hepatocytes are extremely sensible to the variations in trophic stimuli, and this fact may eventually be used in therapeutic manipulations of different liver diseases.

Investigations on the functional aspects of these situations are currently under way in our laboratory. 


\section{ReSUMO}

Objetivos: Estudar em ratos, a repercussão da desnutriçāo calórico-protéica na morfologia hepática, comparativamente com o emagrecimento dos animais e com a reduçāo do tamanho de órgãos não írrigados por sangue esplâncnico como rins e baço. Material e Métodos: Em dois grupos de ratos, um alimentado "ad libitum" e outro sem alimento, só com água por 7 dias, foram deteminadas as modificaçōes no peso dos animais, nas massas do figado, rins e baço, proteína, DNA e relaçăo proteína/DNA no tecido hepático e tamanho dos hepatócitos. Resultados: Foi observado que o fígado diminuiu de massa $(27,41 \%)$ em proporção significantemente maior $(p<0,05)$ que o emagrecimento corpóreo $(19,22 \%)$. Rins e baço tiveram suas massas reduzidas em $18,68 \%$ e $24,28 \%$, respectivamente, semelhante à diminuição do peso corpóreo. A redução da massa hepática ocorreu por hipoplasia e atrofia, respectivamente diminuição no número e no tamanho dos hepatócitos. Conclusão: Concluiu-se que existe um consumo preferencial de proteína hepática na desnutrição calórico-protéica que poderia eventualmente resultar da ação aditiva dos efeitos do consumo geral de reservas orgânicas pela desnutriçāo em si e da redução do estímulo hepatotrófico.

\section{REFERENCES}

1. ADDIS,T.; POO,L.J. \& LEW,W. - The quantities of protein lost by the various organs and tissues of the body during a fast. J. Biol. Chem.,115:111-116,1936.

2. ADDIS,T.; POO,L.J. \& LEW,W. - Protein loss from liver during a two day fast. J. Biol. Chem.,115:117-118,1936.

3. BAKER,A.L. - Hepatotrophic factors: basic concepts and clinical implications. Acta Med. Scand.,703(Suppl.):201208,1985 .

4. BEST,C.H.; HAIST,R.E. \& RIDOUT,J.H. - Diet and the insulin content of pancreas. J. Physiol. (Lond.),97:107$119,1939$.

5. BLACKARD,W.G. \& NELSON,N.C. - Portal and peripheral vein immunoreactive insulin concentrations before and after glucose infusion. Diabetes, 19:302-306,1970.

6. BRUES,A.M.; DRURY,D.R. \& BRUES,M.C. - A quantitative study of cell growth in regenerating liver. Arch. Path.,22:658-673,1936.

7. BUCHER,N.L.R. \& SWAFFIELD,M.N. - Regulation of hepatic regeneration in rats by synergistic action of insulin and glucagon. Proc. Natl. Acad. Sci. USA,72:11571160,1975 .
8. BURTON,K. - A study of the conditions and mechanisms of the diphenylamine reaction for the colorimetric estimation of deoxyribonucleic acid. Biochem. J.,62:315-323,1956.

9. CAHILL,G.F.; HERRERA,M.G.; MORGAN,A.P.; SOELDNER,J.S.;

STEINKE, J.; LEVY,P.L.;REICHARD,G.A.,Jr. \& KIPNIS,D.M. Hormone-fuel interrelationships during fasting. J. Clin. Invest.,45:1751-1769,1966.

10. CAHILL,G.F.,Jr. - Starvation in man. New Engl J. Med. 282:668-675,1970.

11. CAHILL,G.F. - Physiology of insulin in man.Diabetes, 20:785-799,1971.

12. CAHILL,G.F. - Glucagon. New Engl. Med. J.,288:157158,1973 .

13. CARUANA,J.A. \& GAGE,A.A. - Increased uptake of insulin and glucagon by the liver as a signal for regeneration. Surg. Gynec. Obstet.,150:390-394,1980.

14. CORNELL,R.P. - Hyperinsulinemia and hyperglucagonemia in fasted rats during liver regeneration. Am. J. Physiol.,240 (Endocrinol. Metab. 3):E112-E118,1981.

15. DIEHL,A.M. - Nutrition, hormones, metabolism and liver regeneration. Seminars Liver Dis.,11:315-320,1991.

16. DOLAIS-KITABGI,J.; REY,J.F.; FEHLMANN,M.; MORIN,O. \& FREYCHET,P. - Effect of insulin and glucagon 
on amino acid transport in isolated hepatocytes after partial hepatectomy in the rat. Endocrinology,109:868-875,1981.

17. FAJANS,S.S.; FLOYD,J.C.Jr.; KNOPF,R.F. \& CONN,J.W. - Effect of amino acids and proteins on insulin secretion in man. Recent. Progr. Hormone Res.,23:617-662,1967.

18. FARIVAR,M.; WANDS,J.R.; ISSELBACHER,K.J. \& BUCHER,N.R.L. - Effect of insulin and glucagon on fulminant murine hepatitis. N. Engl. J. Med.,295:1517$1519,1976$.

19. FATH,J.; PARKES,B.; SORENSEN,V.; GAYMER,J.; MACDONALD,M.; WARREN,R.; TKACH,D.; FERNANDEZ,F; BLOCK,D.; KONSTANTINIDES,F. \& BIVINS,B. - Fasted state impedes recovery of porcine hepatic oxygen consumption after warm hepatic ischemia. Surgery, 110:742-52,1991.

20. FLOYD,J.C.,Jr.; FAJANS,S.S.; CONN,J.W.; KNOPF,R.F. \& RULL,J.- Stimulation of insulin secretion by amino acids. J. Clin. Invest.,45:1487-1502,1966.

21. FLOYD,J.C.,Jr.; FAJANS,S.S.; PEK,S.; THIFFAULT,C.A.; KNOPF,R.F. \& CONN,J.W. - Synergistic effect of certain amino acid pairs upon insuline secretion in man. Diabetes,19:102-08,1970.

22. FLOYD,J.C.,Jr.; FAJANS,S.S.; PEK,S.; THIFFAULT,C.A.; KNOPF,R.F. \& CONN,J.W. - Synergistic effect of essencial amino acids and glucose upon insuline secretion in man. Diabetes,19:109-15,1970.

23. FRANCAVILLA,A.; OVE,P.; POLIMENO,L.; COETZEE,M.; MAKOWKA,L.; BARONE,M.; VAN THIEL,D.H. \& STARZL,T.E. - Regulation of liver size and regeneration: importance in liver transplantation. Transplant. Proc.,20:494-497,1988.

24. IMAMURA,H.; KAWASAKI,S.; SHIGA,J.; BANDAI,Y.; SANJO,K. \& IDEZUKI,Y. - Quantitative evaluation of parenchymal liver cell volume and total hepatocyte number in cirrhotic patients. Hepatology, 14:448-453,1991.

25. KAM,I.; LYNCH,S.; SVANAS,G.; TODO,S.; POLIMENO,L.; FRANCAVILLA,A.; PENKROT,R.J.; TAKAYA,S.; ERICZON,B.G.; STARZL,T.E. \& VAN THIEL,D.H. - Evidence that host size determines liver size: studies in dogs receiving orthotopic liver transplants. Hepatology,7:362-366,1987.

26. KAWASAKI,S.; MAKUUCHI,M.; ISHIZONE,S.; MATSUNAMI,H.; TERADA,M. \& KAWARAZAKI,H. Liver regeneration in recipients and donors after transplantation. Lancet,339:580-581,1992.

27. KUBOI,H.; MIZOGUCHI,Y.; KAWADA,N.; SAKAGUCHI,H.; SEKI,S.; KOBAYASHI,K. \& MORISAWA,S. - The protective effects of glucagon and insulin in an experimental massive hepatic cell necrosis model. Nippon Shokakibyo Gakkai Zasshi, 87:211217,1990 .

28. LEE,S.S.; MOREAU,R.; HADENGUE,A.; CERINI,R.; KOSHY,A. \& LEBREC,D. - Glucagon selectively increases splanchnic blood flow in patients with well-compensated cirrhosis. Hepatology, 8:1501-1505,1988.
29. LOWRY,O.H.; ROSEBROUGH,N.J.; FARR,A.L.; RANDALL,R.J. - Protein measurement with Folin phenol reagent. J. Biol. Chem.,193:265-275,1951.

30. MADISON,L.L.; COMBES,B.; UNGER,R.H. \& KAPLAN,N. - The relationship between the mechanism of action of the sulfonylureas and the secretion of insulin into the portal circulation. Ann. N. Y. Acad. Sci.,74:548556,1959 .

31. MORTIMORE,G.E. \& TIETZE,F. - Studies on the mechanism of capture and degradation of insulin-I131 by the cyclically perfused rat liver. Ann. N. Y. Acad. Sci., 82:329-337, 1959.

32. OKASAKI,K.; MIYAZAKI,S.; ONISHI,S. \& ITO,K. Effects of food intake and various extrinsic hormones on portal blood flow in patients with liver cirrhosis demonstrated by pulsed doppler with the octoson. Scand. J. Gastroenterol.,21:1029-1030,1986.

33. OSAWA,K.; YAMAOKA,Y.; MANBU,H. \& HONJO,I. Insulin as the primary factor governing changes in mitochondrial metabolism leading to liver regeneration and atrophy. Am. J. Surg.,127:669-75,1974.

34. PARRA,O.M. - Efeitos da Ciclosporina-A Sobre a Regeneração Hepática: Estudo Experimental. São Paulo, 1988. Tese de Doutorado - Fac. Med. Univ. São Paulo.

35. PARRA,O.M.; SAAD,W.A.; FERRAZ NETO,J.B.E.; FERRI,S.; SOUZA e SILVA,R.A.P.; DAL COLLETTO,G.M.D. \& SAAD,W.A.,Jr. - Additional growth of an intact liver induced by exogenous hepatotrophic factors. A study in rats. ABCD Arq.Bras.Cir.Dig.(São Paulo), 7:6468,1992 .

36. PARRA,O.M.; SAAD,W.A.; SOUSA, E SILVA,R.A.P.; HERNANDEZ-BLASQUEZ,F.J.; PEDUTO,L.; FERRAZ NETO,B.H. \& SAAD,W.A.,Jr. - Stimulation of intact rat liver by exogenous hepatotrophic factors with additional growth of its mass. Acta Cir. Bras.,9:7-11,1994.

37. ROUS,P. \& LARIMORE,L.D. - Relation of the portal blood to liver maintenance. J. Exp. Med.,31:609-632,1920.

38. RUBIN,E.; GEVIRTZ,N.R.; COHAN,P.; TOMITA,F. \& JACOBSON II, J.H. - Liver cell damage produced by portacaval shunts. Proc. Soc. exp. Biol. Med.,118:235237,1965 .

39. SIGEL,B.; BALDIA,L.B. \& DUNN,M.R. - Studies of liver lobes autotransplanted outside the abdominal cavity. Surg. Gynec. Obstret.,124:525-530,1967.

40. SIGEL,B.; BALDIA,L.B.; MENDUKE,H. \& FEIGL,P. Independence of hyperplastic and hypertrophic responses in liver regeneration. Surg. Gynec. Obstet.,125:95-100,1967.

41. SKULLMAN,S.; IHSE,I. \& LARSSON,J. - Influence of malnutrition on regeneration and composition of the liver in rats. Acta Chir. Scand.,156:717-722,1990.

42. STARZL,T.E.; FRANCAVILLA.A.; HALGRIMSON,C.G.; FRANCAVILLA,F.R.; PORTER,K.A.; BROWN,T.H. \& PUTNAM,C.W. - The origin, hormonal nature and action of portal venous hepatotrophic substances. Surg. Gynec. Obstet.,137:139-199,1973. 
43. STARZL,T.E.; PORTER,K.A. \& PUTNAM,C.W. Intraportal insulin protects from the liver injury of portacaval shunt in dogs. Lancet,2(7947):1241-1242,1975.

44. STARZL,T.E.; PORTER,K.A.; WATANABE,K.; PUTNAM,C.W, - Effects of insulin, glucagon and insulin/ glucagon infusions on liver morphology and cell division after complete portacaval shunt in dogs. Lancet,1(7964):821825,1976 .

45. STARZL,T.E.; FRANCAVILLA,A.; PORTER,K.E. \& BENICHOU,J. - The effect upon the liver of evisceration with or without hormone replacement. Surg. Gynec. Obstet.,146:524-531,1978.

46. STIRLING,G.A.; BOURNE,L.D. \& MARSH,T. - Effect of protein deprivation and a reduced diet on the regenerating rat liver. Br. J. exp. Path.,56:502-509,1975.

47. TALARICO,K.S.; FELLER,D.D. \& NEVILLE,E.D. - Mitotic response to various dietary conditions in the normal and regenerating rat liver. Proc. Soc. exp. Biol. Med.,136:381384,1971 .

48. UNGER,R.H.; EISENTRAUT,A.M.; MADISON,L.L.; SIMS,K.R. \& WHISSEN,N. - The effects of total starvation upon the levels of circulating glucagon and insulin in man. J. Clin. Invest.,42:1031-1039,1963.

49. UNGER.R.H. - Glucagon and the insulin:glucagon ratio in diabetes and other catabolic illnesses. Diabetes, 20:834838,1971 .

50. VAN THIEL,D.H.; GAVALER,J.S.; KAM,I.; FRANCAVILLA,A.; POLIMENO,L.; SCHADE.R.R.; SMITH,J.; DIVEN,W.; PENKROT,R.J. \& STARZL,T.E.; Rapid growth of an intact human liver transplanted into a recipient larger than the donor. Gastroenterology, 93:14149,1987

51. WHITTEMORE,A.D.; VOORHEES,A.B. \& PRICE,J.B. Hepatic blood flow and pancreatic hormones as modifiers of hepatic regeneration. Surg. Forum,27:363-365, 1976.

52. YAMADA,T.; YAMAMOTO,M.; OZAWA,K. \& HONJO,I. - Insulin requirements for hepatic regeneration following hepatectomy, Ann. Surg.,185:35-42,1977.

53. YOUNG,E.A.; HARRIS,M.M.; CANTU,T.L.; GHIDONI, J.J. \& CRAWLEY,R. - Hepatic response to a very-lowenergy diet and refeeding in rats. Am. J. Clin. Nutr.,57:85762,1993 . 